\title{
ANALISIS PERBANDINGAN PERENCANAAN METODE CPM PROYEK ICCP MENGGUNAKAN VARIASI PELETAKAN GROUNDBED PADA LINE PIPA GAS EKSISTING PERUSAHAAN PUPUK
}

\author{
Vitalia Dian Novita ${ }^{1}$, Bambang Antoko $^{2}$, Pekik Mahardhika ${ }^{3}$ \\ 1,2,3 Politeknik Perkapalan Negeri Surabaya \\ 1,2,3Jl. Teknik Kimia, Kampus ITS Sukolilo - Surabaya \\ E-mail : ${ }^{1}$ vitaliadn015@gmail.com, ${ }^{2}$ bambangantoko@gmail.com, ${ }^{3}$ pekikmahardhika@ppns.ac.id
}

\begin{abstract}
Abstrak
Perusahaan pupuk di Indonesia didirikan untuk memenuhi kebutuhan pertanian dan pangan nasional. Untuk menunjang pelayanan distribusi maupun proses, sistem perpipaan di dalamnya didesain dengan memperhatikan performanya, termasuk pada proteksi katodiknya. Pada salah satu pabrik di perusahaan pupuk yang diteliti sedang memiliki permasalahan proteksi katodik sehingga membutuhkan pergantian sistem proteksi dari SACP yang sudah ada menjadi ICCP. Mengacu pada penelitian sebelumnya dan berdasarkan kondisi area yang sudah ada, variasi penempatan groundbed dapat dilakukan untuk dianalisa mana yang paling tepat digunakan untuk system perpipaan di perusahaan pupuk tersebut. Sebanyak 5 titik lokasi telah dipilih berdasarkan pertimbangan kondisi area sesuai dengan sketsa terlampir. Langkah pertama adalah melakukan perhitungan teknis pada masing-masing variasi, kemudian melakukan perencanaan proyek yang selanjutnya dianalisa keunggulan dari hasil perhitungannya. Dari hasil perhitungan yang telah dilakukan, dapat disimpulkan bahwa sistem ICCP dengan menggunakan 2 groundbed tipe 3 adalah yang paling efektif digunakan untuk system perpipaan eksisting pada pabrik yang diteliti karena memiliki keunggulan terbanyak dibandingkan variasi yang lain.
\end{abstract}

Kata Kunci: groundbed, ICCP, korosi, proteksi katodik

\begin{abstract}
Fertilizer industry established to fulfill national needs in agriculture and food sector. Systems that exist in thatindustry designed safelyto support distribution and process services, including its cathodic protection. In one of fertilizer plant under study, there is a problem on cathodic protection system in its underground gas pipe, so countermeasures must be done. The preinstalled SACP system with less protection resulting many recommendations to change the system into ICCP system. Refer to previous research and based on the existing conditions, variations of groundbed laying can be done to analyze which one is the most suitable for piping system in that plant. 5 point locations have been selected in the area according to the attached sketch. The first step carried out is to calculate technical needs on each variation, then plan the management project on each variation. The last stepis to do comparative analysis of each variation. Finally, it can be concluded in technical and aconomical point of view that ICCP system using 2 groundbed type 3 is the most effective one used for fertilizer plant under study because it has the most advantageous compared to the other variations.
\end{abstract}

Keywords: cathodic protection, corrosion, groundbed, ICCP

\section{PENDAHULUAN}

Perusahaan pupuk yang ada di Indonesia didirikan untuk memenuhi kebutuhan nasional dalam bidang pertanian dan pangan yang semakin hari semakin meningkat. Demi menunjang semua pelayanan distribusi dan proses, sistem jaringan pipa dan instrumen lain didesain dengan aman dan ramah lingkungan. Salah satunya yaitu sistem perpipaan aboveground maupun underground yang dirancang 
dengan memperhatikan performanya. Hal ini bertujuan untuk menghindari adanya kegagalan sistem seperti kurangnya tekanan dan kecepatan aliran fluida (Mahardhika, 2018). Namun ada salah satu masalah yang sering timbul dalam proses ini yaitu peristiwa korosi. Hal ini juga terjadi pada salah satu pabrik pupuk yang sedang diteliti.

Korosi adalah peristiwa alamiah yang ditandai dengan adanya degradasi material karena bereaksi dengan lingkungannya. Korosi tidak dapat dicegah atau dihilangkan, namun masih bisa dikendalikan dengan menurunkan lajunya. Salah satu cara yang dipakai untuk mengendalikan korosi pada pabrik pupuk yang diteliti adalah dengan menggunakan proteksi katodik.

Berdasarkan data dari Departemen Inspeksi Teknik pabrik tersebut, proteksi katodik metode SACP telah digunakan sebelumnya. Namun, ada permasalahan proteksi sehingga muncul rekomendasi pergantian sisten proteksi katodik metode SACP menjadi ICCP. Dengan memperhatikan lahan yang ada, variasi peletakan groundbed dapat dilakukan untuk mendapatkan proteksi katodik ICCP yang paling sesuai dari analisa perbandingan perencanaan proyeknya.

Pada penelitian dengan judul "Analisis Perbandingan Perencanaan Metode CPM Proyek ICCP Menggunakan Variasi Peletakan Groundbed pada Line Pipa Gas Eksisting Perusahaan Pupuk" ini pada dasarnya merujuk penelitian sebelumnya dengan judul "Analisa Pengaruh Variasi Jumlah Groundbedterhadap Kebutuhan Tegangan Proteksi pada Metode Proteksi Katodik ICCP untuk Underground Trunkline PGDP" dengan memvariasikan peletakan groundbed pada ICCP sehingga dapat diketahui lokasi groundbed yang paling sesuai untuk pabrik yang diteliti tersebut.

\section{- Manajemen Biaya Perencanaan}

Dalam manajemen, perencanaan adalah sebuah acuan untuk mempermudah seorang manajer agar tercapai sebuah tujuan, membuat strategi untuk mencapai tujuan itu, dan mengembangkan rencana aktivitas kerja organisasi. Perencanaan merupakan proses terpenting dari semua fungsi manajemen karena tanpa perencanaan fungsi-fungsi lain pengorganisasian, pengarahan, dan pengontrolan tak akan dapat berjalan.

Hal terpenting yang harus dilakukan pada manajemen proyek adalah membuat jaringan kerja (project network planning). Jaringan kerja merupakan salah satu analisis teknik riset operasional yang menghubungkan dengan manajemen proyek. Teknik analisis jaringan kerja yang dikembangkan dalam perencanaan, penjadwalan, dan pengendalian proyek. Ada dua teknik analisis yang dikembangkan yaitu sebagai berikut:

1. Metode jalur Kritis (Critical Path Method)

2. Metode PERT (Project Evaluation and Risk Technique).

\section{- Korosi}

Korosi adalah perusakan atau penurunan mutu dari material akibat bereaksi dengan lingkungan (Fontana, 1987). Dalam kehidupan sehari-hari, sering kita jumpai penggunaan istilah korosi yang disama artikan dengan karat. Dua kata ini sebenarnya tidak sama. Karat adalah istilah produk korosi yang lebih dikhususkan untuk logam besi (ferrous). Sedangkan istilah korosi seharusnya dimaksudkan dengan cakupan yang lebih luas dan secara umum untuk material baik logam maupun non logam.

\section{- Proteksi Katodik (Cathodic Protection)}

Proteksi katodik (Cathodic Protection) merupakan teknik yang digunakan untuk pengendalian korosi pada permukaan logam dengan menjadikan permukaan logam tersebut sebagai katoda dari sel elektrokimia (NACE RP 0169, 2002). Proteksi katodik ini merupakan metode yang umum digunakan untuk melindungi struktur logam dari korosi. Sistem proteksi katodik ini biasanya digunakan untuk melindungi baja, jalur pipa, tangki, tiang pancang, kapal, anjungan lepas pantai, dan casing (selubung) sumur minyak di darat. Efek samping dari penggunaan yang tidak tepat adalah timbulnya molekul hidrogen yang dapat terserap ke dalam logam sehingga menyebabkan hydrogen embrittlement (kegetasan hidrogen).

Ditinjau dari sumber listriknya, metode proteksi katodik dibagi menjadi dua, yaitu metode anoda korban (sacrificial anode) dan metode arus tanding (Impressed Current).

\section{- Proteksi Katodik Arus Tanding (Impressed} Current Cathodic Protection)

Prinsip dari metode anoda arus tanding ini adalah melindungi logam dengan cara mengalirkan arus lisrtik searah yang diperoleh dari sumber luar, biasanyadari penyearah arus (transformer rectifier), dimana kutub negatif dihubungkan ke logam yang dilindungi dan kutub positif dihubungkan ke anoda (NACE RP 0572, 2001). Dimana material anoda yang bias digunakan dalam metode arus tanding adalah logam yang konduktif dan mempunyai sifat inert atau semi consumable.

\section{- Groundbed}

Secaradefinisi, groundbed adalah satu atau lebih anoda yang dipasang di bawah permukaan tanah 
dengan tujuan untuk melakukan proteksi katodik (Baboian, 2002). Secara bentuknya, groundbed dibedakan menjadi 2 yaitu vertical groundbed dan horizontal groundbed. Dalam penggunaan pada lapangan, vertical groundbed lebih banyak digunakan karena selain menghemat tempat secara horizontal, tipe ini digunakan untuk mendapatkan resestivitas tanah yang lebih kecil karena resistivitas tanah pada permukaan yang sangat tinggi.

Dalam penelitian ini groundbed yang digunakan adalah vertical groundbed.S edangkan dilihat dari segi pemasangannya, tipe groundbed dibagi menjadi 2 macam (Kurniawantoro, Wismawati, \& Bisono, 2017) yaitu:

\section{Shallow Groundbed}

Shallow groundbed adalah groundbed yang terdiri dari satu atau lebih anoda yang dipasang secara vertikal atau horizontal dengan kedalaman kurang dari $15 \mathrm{~m}(50 \mathrm{ft})$.

\section{Deep Groundbed}

Deep gorundbed adalah tipe groundbed yang terdiri dari satu atau lebih anoda yang dipasang secara vertikal dengan kedalaman $15 \mathrm{~m}$ atau lebih di bawah permukaan tanah dalam suatu lubang.

- Perhitungan Teknis ICCP (Adam, Prasojo, \& Mahardhika, 2016):

1. Arus Proteksi

Nilai arus proteksi yang digunakan dapat diketahui dengan menggunakan persamaan berikut :

$I_{t}=S A \times C D$

2. Hambatan Sirkuit Keseluruhan

Nilai hambatan sirkuit keseluruhan sangat mempengaruhi nilai dari tegangan proteksi yang digunakan. Untuk mengetahuinya dapat digunakan persamaan berikut :

$$
\begin{aligned}
& R_{a}=\frac{R_{B}}{2 \times \pi \times L_{a}} \times \ln \left[\left(\frac{8 \times L_{a}}{D_{a}}\right)-1\right] \\
& R_{B R}=\frac{\text { Resistivitas tanah }}{2 \times \pi \times L_{b}} \times \ln \left[\left(\frac{8 \times L_{b}}{d_{b}}\right)-1\right] \\
& R_{G B}=\frac{R_{a}}{N_{a}} \times f_{a}+R_{B R} \\
& R_{C}=\frac{L_{c} \times R_{c S}}{N \times C} \\
& R_{\text {pos }}=R_{g b}+R_{\text {kabel-pos }}
\end{aligned}
$$

\section{Tegangan Proteksi}

Nilai dari tegangan proteksi yang digunakan untuk proteksi dengan metode ICCP dapat digunakan persamaan berikut :

$V_{D C}=\left[\left(I_{t} \times R_{t}\right) x\left(1+s f_{3}\right)\right]+B_{e m f}$

\section{METODE}

Metode yang digunakan dalam penelitian ini adalah dengan menganalisa perbandingan tipe proteksi ICCP dengan memvariasikan lokasi penempatan groundbednya. Pemilihan lokasi didasarkan pada kondisi eksisting yang sudah ada. Kelima variasi tersebut adalah dengan menggunakan 1 groundbed terpusat, 2 groundbed tipe 1 (diletakkan antara ujung area), 2 groundbed tipe 2 (diletakkan di tengah area dengan jarak tertentu), 2 groundbed tipe 3 (diletakkan di tengah area mendekati TR) dan 3 grundbed yang diletakkan menyebar.

Langkah awal dengan melakukan perhitungan kebutuhan teknis pada seluruh variasi peletakan groundbed. Langkah kedua adalah dengan melakukan perencanaan proyek pada setiap variasi sehingga didapatkan hasil berupa biaya proyek yang meliputi biaya komponen dan biaya tenaga kerja. Langkah ketiga adalah melakukan analisa perbandingan dari segi teknis maupun ekonomis berdasarkan hasil yang sudah didapat sehingga didapatkan tipe proteksi yang paling efektif untuk dipakai pada sistem perpipaan pabrik yang diteliti. Berikut Gambar 1 merupakan diagram alir penelitian:

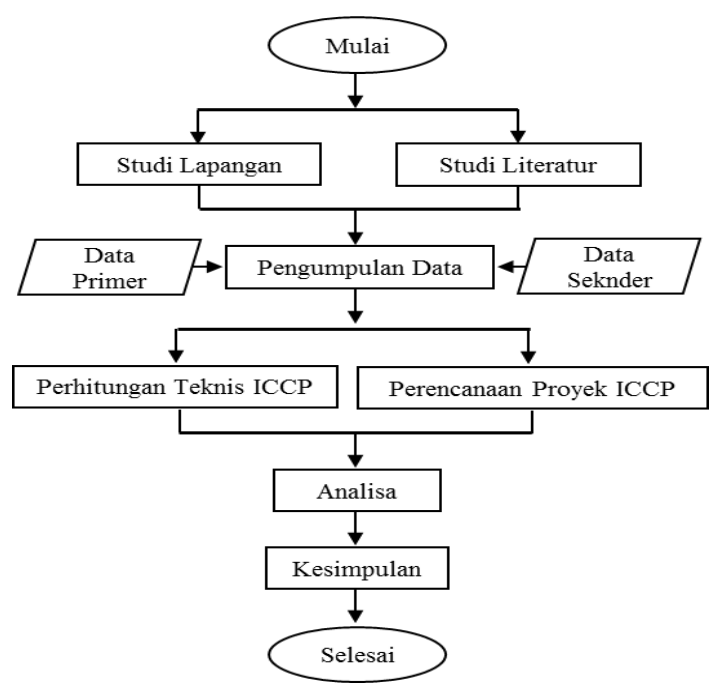

Gambar 1. Diagram Alir Penelitian

Variasi sistem proteksi yang akan didesain dipilih berdasarkan situasi dan kondisi yang ada pada pabrik terkait. Hal yang tidak kalah penting dalam pemilihan lokasi perancangan adalah dengan memperhatikan resistivitas tanahnya. Berikut merupakan rincian variasinya:

\section{ICCP 1 Groundbed Terpusat}


Pada variasi ini, groundbed diletakkan persis di tengah area yang diproteksi. Jarak antara Positive Junction Box ke Groundbed 1 sejauh 26 meter.

\section{ICCP 2 Groundbed Tipe 1}

Pada variasi ini, desain sistem proteksi katodik metode ICCP dilakukan dengan menggunakan 2 groundbed yang diletakkan di masing-masing ujung titik terjauh pipa. Jarak antaraPositive Junction Box ke Groundbed 1 sejauh 63 meter dan jarak antara Positive Junction Box ke Groundbed 2 sejauh 230 meter.

\section{ICCP 2 Groundbed Tipe 2}

Pada variasi ini, desain sistem proteksi katodik metode ICCP dilakukan dengan menggunakan 2 groundbed yang diletakkan di tengah area yang diproteksi.Jarak antara Positive Junction Box ke Groundbed 1 sejauh 55 meter dan jarak antara Positive Junction Box ke Groundbed 2 sejauh 95 meter.

\section{ICCP 2 Groundbed Tipe 3}

Pada variasi ini, desain sistem proteksi katodik metode ICCP dilakukan dengan menggunakan 2 groundbed yang diletakkan di tengah area yang diproteksi. Jarak antara Positive Junction Box ke Groundbed 1 sejauh 10 meter dan jarak antara Positive Junction Box ke Groundbed 2 sejauh 15 meter.

\section{ICCP 3 Groundbed Terpusat}

Pada variasi ini, desain sistem proteksi katodik metode ICCP dilakukan dengan menggunakan 3 groundbed yang diletakkan menyebar pada area proteksi. Jarak antara Positive Junction Box ke Groundbed 1 sejauh 63 meter, antara Positive Junction Box ke Groundbed 2 sejauh 25 meter, dan jarak antara Positive Junction Box ke Groundbed 3 sejauh 230 meter.

\section{HASIL DAN PEMBAHASAN}

Dalam penelitian ini, diperoleh hasil perhitungan teknis dari tiap variasi peletakan groundbed sesuai dengan Tabel 1.

Berdasarkan informasi dari Tabel 1, dapat ditentukan beberapa komponen untuk desain proteksi katodik yang berbeda-beda pada setiap variasi sehingga dapat diperoleh total biaya komponen yang digunakan untuk perencanaan proyek.
Tabel 1. Hasil Perhitungan Teknis Variasi Peletakan Groundbed

\begin{tabular}{|l|c|}
\hline \multicolumn{1}{|c|}{$\begin{array}{c}\text { Variasi } \\
\text { Groundbed }\end{array}$} & $\begin{array}{c}\text { Tegangan } \\
\text { Proteksi (V) }\end{array}$ \\
\hline 1 Groundbed Terpusat & 3,4398 \\
\hline 2 Groundbed Tipe 1 & 3,4596 \\
\hline 2 Groundbed Tipe 2 & 3,4546 \\
\hline 2 Groundbed Tipe 3 & 3,4268 \\
\hline 3 Groundbed Tersebar & 3,5178 \\
\hline
\end{tabular}

Berikut Tabel 2 merupakan komponen detail ICCP yang dipakai untuk perencanaan proyek pada perusahaan pupuk yang diteliti beserta harga satuannya:

Tabel 2. Komponen Detail Perencanaan Proyek ICCP

\begin{tabular}{|c|c|c|}
\hline ITM & DESCRIPTION & $\begin{array}{l}\text { PRICE } \\
\text { (Rupiah) }\end{array}$ \\
\hline 1 & $\begin{array}{l}\text { Transformator Rectifier } \\
\text { Manufacturer : NCE } \\
\text { Input : } 1 \text { phase, } 50 \mathrm{~Hz} \\
\text { Output : } 5 \mathrm{~A}-20 \mathrm{~V}\end{array}$ & 90.000 .000 \\
\hline 2 & $\begin{array}{l}\text { Canyster type High Silicon } \\
\text { Cast Iron for soil + coke } \\
\text { breeze application, max } \\
\text { current output } 2,5 \text { A. tail } 5 \\
\text { m long. Cable size ( } 16 \\
\text { sqmm) } \\
\text { Cu/PVDF/HMWPE, } \\
\text { prepacked in steel canister } \\
\text { dia } 200 \text { mm x length } 2500 \\
\text { mm. Anode net weight } 29 \\
\mathrm{Kg} \text {. }\end{array}$ & 18.000 .000 \\
\hline \multirow{3}{*}{3} & \multicolumn{2}{|l|}{ Cable } \\
\hline & $\begin{array}{l}\text { PVDF-1C-16mm }{ }^{2}-46 A- \\
1,15 \times 10^{-3} \Omega / \mathrm{m}\end{array}$ & 70.000 \\
\hline & $\begin{array}{l}\text { NYFGbY-4C-16mm }{ }^{2}- \\
101 \mathrm{~A}-1,15 \times 10^{-3} \Omega / \mathrm{m}^{-}\end{array}$ & 280.000 \\
\hline 4 & $\begin{array}{l}\text { ICS Cast Alumunium } \\
\text { Junction Box } \\
\text { dimension : } 300 \times 200 \times \\
140 \mathrm{~mm}\end{array}$ & 17.000 .000 \\
\hline 5 & $\begin{array}{l}\text { ICS Cast Alumunium Test } \\
\text { Box }\end{array}$ & 3.000 .000 \\
\hline 6 & $\begin{array}{l}\text { ICS Cast Alumunium } \\
\text { Bonding Terminal Box }\end{array}$ & 15.000 .000 \\
\hline 7 & $\begin{array}{l}\text { Zinc reference cell } \\
\text { "Staperm" Underground } \\
\left(\mathrm{ZnSO}_{4}\right) \text {, Model ZN-4-UG } \\
\text { W/ 50' 14-AWG } \\
\text { Yellow RHHW }\end{array}$ & 7.000 .000 \\
\hline 8 & \multicolumn{2}{|l|}{ Thermitweld equi } \\
\hline
\end{tabular}




\begin{tabular}{|c|c|c|}
\hline & $\begin{array}{l}\text { Thermoweld Mould for } \\
\text { cable horisontal connection } \\
\text { : CV-1C-14mm² }\end{array}$ & \multirow{4}{*}{11.000 .000} \\
\hline & Flint Gun & \\
\hline & $\begin{array}{l}\text { Cadweld Charge CA-15 (20 } \\
\text { ea / box) }\end{array}$ & \\
\hline & $\begin{array}{l}\text { Royston Handycap (20 } \\
\text { ea/box) }\end{array}$ & \\
\hline 9 & $\begin{array}{l}\text { Splicing kit and split bolt } \\
\text { connector }\end{array}$ & 2.000 .000 \\
\hline
\end{tabular}

Berdasarkan Tabel 1 dan Tabel 2, didapatkan total biaya komponen yang berbeda pada masingmasing variasi tipe proteksi seperti yang disajikan pada Tabel 3 berikut:

Tabel 3. Biaya Komponen Variasi Peletakan Groundbed

\begin{tabular}{|c|c|}
\hline Tipe Proteksi Katodik & $\begin{array}{c}\text { Total Harga } \\
(\mathbf{R p})\end{array}$ \\
\hline 1 Groundbed Terpusat & 256.460 .000 \\
\hline 2 Groundbed Tipe 1 & 275.150 .000 \\
\hline 2 Groundbed Tipe 2 & 265.140 .000 \\
\hline 2 Groundbed Tipe 3 & 256.390 .000 \\
\hline 3 Groundbed Tersebar & 276.900 .000 \\
\hline
\end{tabular}

Setelah mengetahui biaya komponen yang dibutuhkan, selanjutnya adalah melakukan perhitungan biaya tenaga kerja yang dipakai pada masing-masing variasi tipe proteksi. Langkah awal perencanaan adalah dengan membuat Work Breakdown Structure (WBS).

Setelah pembuatan WBS, dapat ditentukan urutan item pekerjaan dengan durasi masing-masing yang telah ditentukan untuk dijadikan jaringan kerja proyek pada masing-masing variasi. Berikut Tabel 4 merupakan item pekerjaan proyek instalasi sistem ICCP:

Tabel 4. Item Pekerjaan Instalasi ICCP

\begin{tabular}{|l|l|c|}
\hline No. & Aktivitas Pekerjaan & $\begin{array}{l}\text { Simbol } \\
\text { Kegiatan }\end{array}$ \\
\hline 1 & $\begin{array}{l}\text { Pengeboran lubang groundbed } \\
\text { (GB 1) }\end{array}$ & A \\
\hline 2 & $\begin{array}{l}\text { Lowering anoda, } \\
\text { penimbunan(GB 1) }\end{array}$ & B \\
\hline 3 & $\begin{array}{l}\text { Pemasangan kabel anoda - } \\
\text { PJB(GB 1) }\end{array}$ & C \\
\hline 4 & $\begin{array}{l}\text { Pemasangan kabel PJB - } \\
\text { TR(GB 1) }\end{array}$ & D \\
\hline 5 & $\begin{array}{l}\text { Pemasangan Zinc Reference } \\
\text { Anode (GB 1) }\end{array}$ & E \\
\hline 6 & $\begin{array}{l}\text { Welding thermit kabel NJB - } \\
\text { pipa(GB 1) }\end{array}$ & F \\
\hline
\end{tabular}

\begin{tabular}{|c|c|c|}
\hline 7 & $\begin{array}{l}\text { Welding thermit kabel pipa - } \\
\text { Test box (GB 1) }\end{array}$ & G \\
\hline 8 & $\begin{array}{l}\text { Pemasangan kabel pipa - } \\
\text { TR(GB 1) }\end{array}$ & $\mathrm{H}$ \\
\hline 9 & Pekerjaan sipil(GB 1) & I \\
\hline 10 & Terminasi kabel(GB 1) & $\mathrm{J}$ \\
\hline 11 & $\begin{array}{l}\text { Pengeboran lubang groundbed } \\
\text { (GB 2) }\end{array}$ & $\mathrm{A} 2$ \\
\hline 12 & $\begin{array}{l}\text { Lowering anoda, penimbunan } \\
\text { (GB 2) }\end{array}$ & B2 \\
\hline 13 & $\begin{array}{l}\text { Pemasangan kabel anoda - } \\
\text { PJB (GB 2) }\end{array}$ & $\mathrm{C} 2$ \\
\hline 14 & $\begin{array}{l}\text { Pemasangan kabel PJB - TR } \\
\text { (GB 2) }\end{array}$ & $\mathrm{D} 2$ \\
\hline 15 & $\begin{array}{l}\text { Pemasangan Zinc Reference } \\
\text { Anode (GB 2) }\end{array}$ & E2 \\
\hline 16 & $\begin{array}{l}\text { Welding thermit kabel NJB - } \\
\text { pipa (GB 2) }\end{array}$ & $\mathrm{F} 2$ \\
\hline 17 & $\begin{array}{l}\text { Welding thermit kabel pipa- } \\
\text { Test box (GB 2) }\end{array}$ & $\mathrm{G} 2$ \\
\hline 18 & $\begin{array}{l}\text { Pemasangan kabel pipa - TR } \\
\text { (GB 2) }\end{array}$ & $\mathrm{H} 2$ \\
\hline 19 & Pekerjaan sipil (GB 2) & $\mathrm{I} 2$ \\
\hline 20 & Terminasi kabel (GB 2) & $\mathrm{J} 2$ \\
\hline 21 & $\begin{array}{l}\text { Pengeboran lubang groundbed } \\
\text { (GB 3) }\end{array}$ & A3 \\
\hline 22 & $\begin{array}{l}\text { Lowering anoda, penimbunan } \\
\text { (GB 3) }\end{array}$ & B3 \\
\hline 23 & $\begin{array}{l}\text { Pemasangan kabel anoda - } \\
\text { PJB (GB 3) }\end{array}$ & $\mathrm{C} 3$ \\
\hline 24 & $\begin{array}{l}\text { Pemasangan kabel PJB - TR } \\
\text { (GB 3) }\end{array}$ & D3 \\
\hline 25 & $\begin{array}{l}\text { Pemasangan Zinc Reference } \\
\text { Anode (GB 3) }\end{array}$ & E3 \\
\hline 26 & $\begin{array}{l}\text { Welding thermit kabel NJB - } \\
\text { pipa (GB 3) }\end{array}$ & F3 \\
\hline 27 & $\begin{array}{l}\text { Welding thermit kabel pipa- } \\
\text { Test box (GB 3) }\end{array}$ & G3 \\
\hline 28 & $\begin{array}{l}\text { Pemasangan kabel pipa - TR } \\
\text { (GB 3) }\end{array}$ & $\mathrm{H} 3$ \\
\hline 29 & Pekerjaan sipil (GB 3) & $\mathrm{I} 3$ \\
\hline 30 & Terminasi kabel (GB 3) & $\mathrm{J} 3$ \\
\hline
\end{tabular}

Jaringan kerja proyek dengan metode CPM sesuai dengan item pekerjaan dapat dirancang dengan memperhatikan durasi proyek yang telah ditentukan sebelumnya serta urutan pekerjaan proyek yang sudah sesuai. Pada metode ini, hal mendasar yang membedakan jaringan kerjanya hanya terletak pada jumlah groundbed yang akan direncanakan. Berikut Gambar 2a, 2b dan 2c merupakan jaringan kerja proyek pada setiap variasi: 


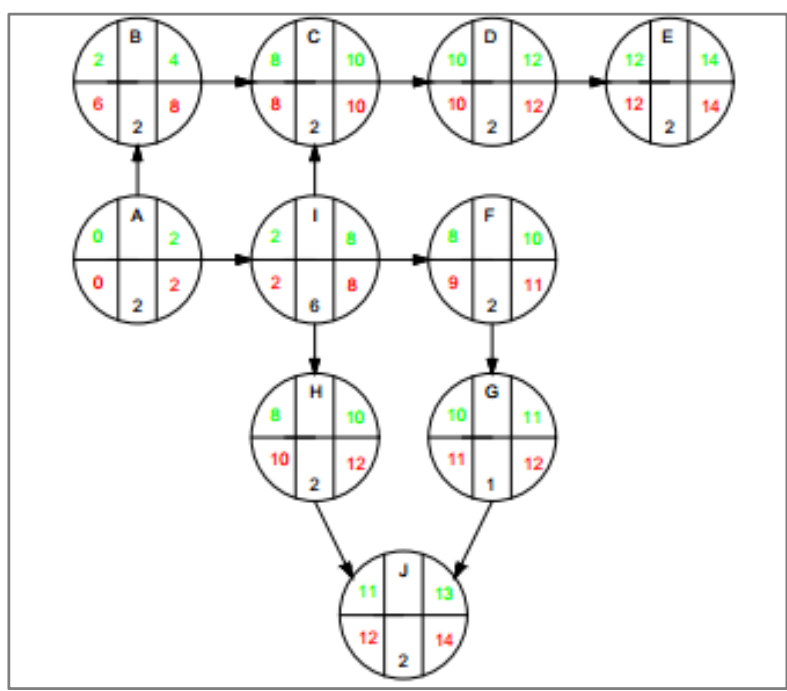

Gambar 2a. Jaringan Kerja Proyek 1 Groundbed Terpusat dengan CPM A-I-C-D-E

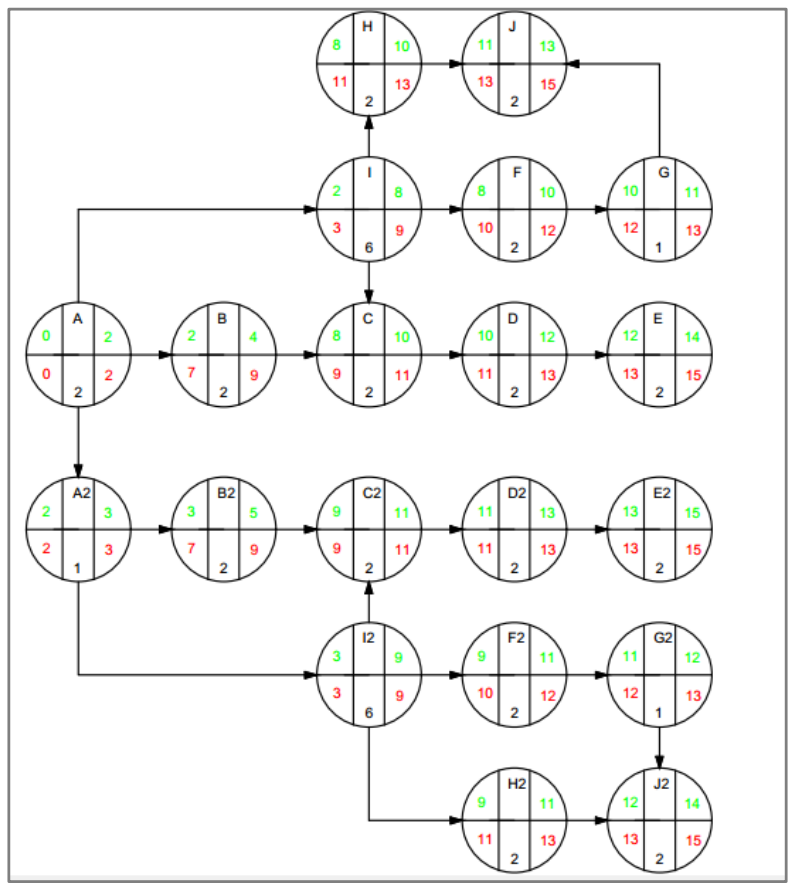

Gambar 2b. Jaringan Kerja Proyek 2Groundbed Tipe 1, 2 dan 3 dengan CPM A-A2-I2-C2-D2-E2

Tabel 5. Biaya Tenaga Kerja Proyek Variasi Peletakan Groundbed

\begin{tabular}{|c|c|}
\hline Tipe Proteksi Katodik & $\begin{array}{c}\text { Total Harga } \\
\text { (Rp) }\end{array}$ \\
\hline 1 Groundbed Terpusat & 39.881 .385 \\
\hline 2 Groundbed Tipe 1 & 74.031 .963 \\
\hline 2 Groundbed Tipe 2 & 74.031 .963 \\
\hline 2 Groundbed Tipe 3 & 74.031 .963 \\
\hline 3 Groundbed Tersebar & 107.637 .142 \\
\hline
\end{tabular}

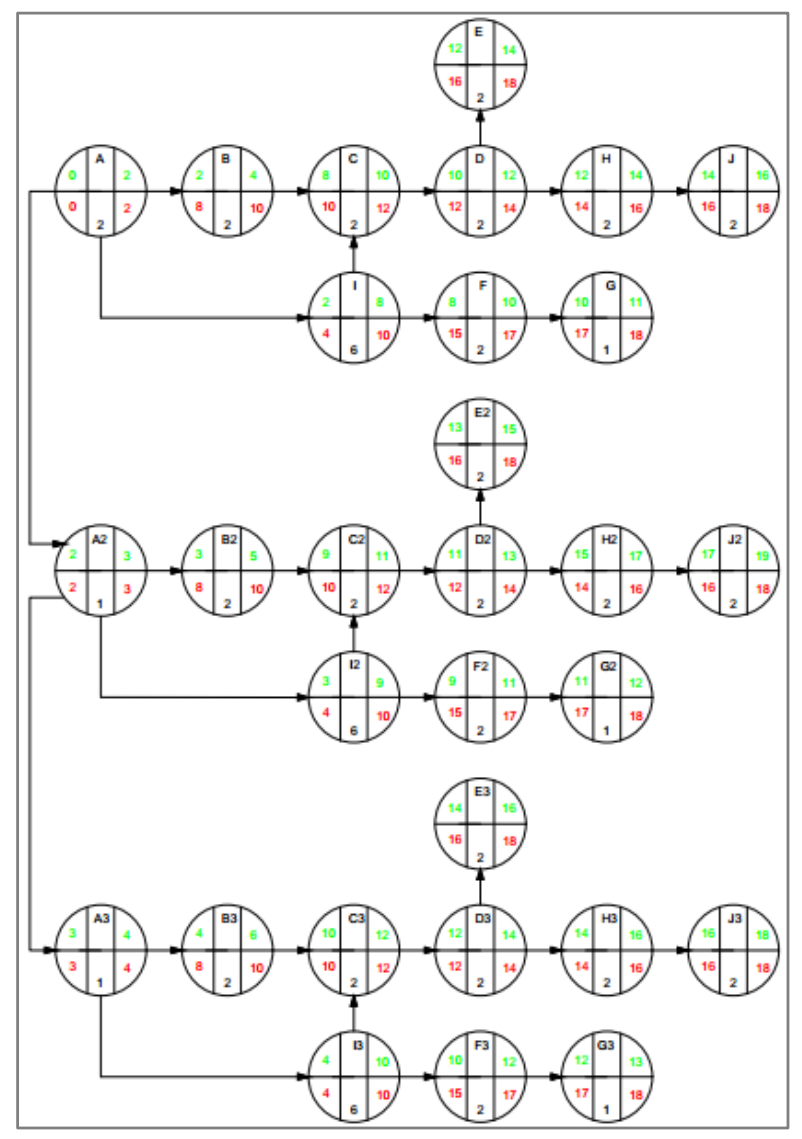

Gambar 2c. Jaringan Kerja Proyek 3Groundbed Tersebar dengan CPM A-A2-A3-I3-C3-D3-H2-J3

Dari hasil rancangan jaringan kerja, didapatkan rincian man power yang dibutuhkan pada masingmasing proyek. Setelah melakukan analisa man power, dapat diperoleh biaya tenaga kerja sesuai dengan man power dan upah pekerja yang sedang berlaku sesuai dengan Tabel 5 di atas.

Berdasarkan hasil perhitungan teknis maupun ekonomis yang diperoleh, dapat ditentukan keunggulan masing-masing variasi tipe proteksi. Berikut Tabel 6 merupakan analisa keunggulan variasi tipe proteksi dari segi teknis maupun ekonomis:

Tabel 6. Analisa Keunggulan Variasi Tipe Proteksi

\begin{tabular}{|c|c|c|c|c|c|c|}
\hline No & Keunggulan & $\begin{array}{c}1 \\
\text { Gb } \\
\text { Ter- } \\
\text { pus } \\
\text { at }\end{array}$ & $\begin{array}{c}2 \\
\text { Gb } \\
\text { Tip } \\
\text { e } 1\end{array}$ & $\begin{array}{c}2 \\
\text { Gb } \\
\text { Tip } \\
\text { e } 2\end{array}$ & $\begin{array}{c}2 \\
\text { Gb } \\
\text { Tip } \\
\text { e } 3\end{array}$ & $\begin{array}{c}3 \\
\text { Gb } \\
\text { Ter- } \\
\text { seb } \\
\text { ar }\end{array}$ \\
\hline 1 & $\begin{array}{l}\text { Tegangan } \\
\text { terkecil }\end{array}$ & & & & V & \\
\hline 2 & $\begin{array}{l}\text { Mencegah } \\
\text { adanya } \\
\text { protection } \\
\text { failure }\end{array}$ & & V & $\mathrm{v}$ & V & v \\
\hline 3 & $\begin{array}{l}\text { Kemudahan } \\
\text { maintenance }\end{array}$ & V & & & & \\
\hline
\end{tabular}




\begin{tabular}{|l|l|l|l|l|l|l|}
\hline & $\begin{array}{c}\text { Meminimalis } \\
\text { ir adanya } \\
\text { range } \\
\text { proteksi yang } \\
\text { terlalu lebar }\end{array}$ & & $\mathrm{v}$ & $\mathrm{v}$ & $\mathrm{v}$ & $\mathrm{V}$ \\
\hline 5 & $\begin{array}{c}\text { Biaya } \\
\text { komponen } \\
\text { terkecil }\end{array}$ & & & $\mathrm{V}$ & \\
\hline 6 & $\begin{array}{c}\text { Biaya tenaga } \\
\text { kerja terkecil }\end{array}$ & $\mathrm{V}$ & & & & \\
\hline 7 & $\begin{array}{c}\text { Jaringan } \\
\text { kerja proyek } \\
\text { paling efektif }\end{array}$ & $\mathrm{V}$ & & & \\
\hline
\end{tabular}

Berdasarkan Tabel 6, didapatkan hasil analisa keseluruhan untuk masing-masing tipe proteksi dilihat dari masing-masing keunggulan dari berbagai segi. Hasil analisa menunjukkan bahwa tipe proteksi katodik sistem ICCP dengan menggunakan 2 groundbed tipe 3 merupakan rancangan sistem yang paling efektif dipakai untuk line pipa gas perusahaan pupuk yang diteliti.

\section{PENUTUP}

\section{Kesimpulan}

Berdasarkan keseluruhan rangkaian penelitian dengan judul "Analisis Perbandingan Perencanaan Metode CPM Proyek ICCP Menggunakan Variasi Peletakan Groundbed pada Line Pipa Gas Perusahaan Pupuk" yang telah dilakukan, dapat diambil kesimpulan sebagai berikut:

1. Pengaruh variasi peletakan groundbed pada sistem ICCP mempengaruhi hasil tegangan proteksi yang dikeluarkan, yaitu 3,4398 volt untuk 1 groundbed terpusat; 3,4596 volt untuk 2 groundbed tipe 1; 3,4546 volt untuk 2 groundbed tipe 2; 3,4268 volt untuk 2 groundbed tipe 3; dan 3,5178 volt untuk 3 groundbed tersebar.

2. Semakin kecil tegangan proteksi yang dihasilkan, maka semakin efektif sistem yang dipakai untuk proteksi katodik.

3. Variasi peletakan groundbed memiliki pengaruh pada perhitungan biaya dengan hasil yang berbeda-beda. Untuk 1 groundbed terpusat membutuhkan biaya total sebesar 296,34 juta rupiah; 2 groundbed tipe 1 sebesar 349,18 juta rupiah; 2 groundbed tipe 2 sebesar 339,17 juta rupiah; 2 groundbed tipe 3 sebesar 330,42 juta rupiah; dan 3 groundbed tersebar membutuhkan biaya total sebesar 384,54 juta rupiah.

4. Tipe sistem proteksi katodik ICCP yang paling efektif dirancang untuk line pipa gas bawah tanah Pabrik Pupuk yang diteliti adalah menggunakan 2 groundbed tipe 3 dengan peletakan groundbed berdekatan dengan transformator rectifier karena memiliki keunggulan paling banyak dibandingkan dengan variasi lainnya.

\section{Saran}

Penelitian mengenai variasi peletakan groundbed pada proteksi katodik ICCP ini dapat dikembangkan menjadi beberapa penelitian baru antara lain:

1. Pengaruh jenis groundbed terhadap manajemen perancangan proteksi katodik sistem ICCP.

2. Pengaruh resistivitas tanah terhadap kebutuhan teknis dan ekonomis proteksi katodik ICCP.

3. Analisa perancangan sistem proteksi katodik dengan menggunakan Program Evaluation and Review Technique (PERT).

4. Analisa perancangan sistem proteksi katodik ICCP dengan menggunakan metode 'CRASHING'.

\section{Ucapan Terima Kasih}

Penulis menyadari penyusunan penelitian ini tidak terlepas dari bantuan dan bimbingan berbagai pihak.Oleh karena itu penulis menyampaikan terima kasih kepada:

1. Civitas akademika Program Studi Teknik Perpipaan Jurusan Teknik Permesinan Kapal yang telah memberikan bimbingan dan pengarahan selama pengerjaan penelitian.

\section{DAFTAR PUSTAKA}

Adam, D. N., Prasojo, B., \& Mahardhika, P. (2016). Analisa Perbandingan SACP dan ICCP sebagai Proteksi Katodik untuk Underground Trunkline PGDP. 1st Conference on Piping Engineering and Its Application (pp. 92-97). Surabaya: PPNS.

Baboian, R. (2002). NACE CORROSION ENGINEER'S REFERENCE BOOK Third Edition. Texas: NACE INTERNATIONAL.

Fontana, M. (1987). Corrosion Engineering. Singapore: McGraw-Hill Book Company.

Kurniawantoro, F., Wismawati, E., \& Bisono, F. (2017). Analisa Pengaruh Variasi Jumlah Groundbed Terhadap Kebutuhan Tegangan Proteksi Pada Metode Proteksi Katodik ICCP Untuk Underground Trunkline PGDP. 2nd Conference Piping Engineering and It's Application (pp. 610-613). Surabaya: Teknik Perpipaan - PPNS.

Mahardhika, P. (2018). EVALUASI INSTALASI PLUMBING AIR BERSIH RUMAH TIPE 42 MENGGUNAKAN PIPE FLOW EXPERT BERDASARKAN SNI 03-7065- 
2005 DAN BS 6700. JTT (Jurnal Teknologi Terapan), 1-6.

NACE RP 0169. (2002). Control of External Corrosion on Underground or Submerged Metallic Piping Systems. Texas: NACE International.

NACE RP 0572. (2001). Design, Installation, Operation, and Maintenance of Impressed Current Deep Groundbeds. Texas: NACE International. 